\title{
REPORT OF THE COUNCIL \\ OF \\ THE CAMDEN SOCIETY, \\ ELECTED 2nd MAY, 1860.
}

ThE Council elected on the 2nd of May, 1860, regret to report the deaths, during the past year, of the following Members :-

The Right Hon. the Earl of Aberdenn.

The Rev. Dr. Bandinet.

Sir Henry Bunbury, K.C.B.

George Godfrey Cunningham, Esq.

Miss Richardson Currer.

Henry Curwen, Esq.

Mrs. HaLL.

Charleg William Haluett, Esq.

Thomas Mason, Esq. F.S.A.

Sir John E. Swinburne, Bart. Pres. Soc. Ant. Newcastle.

Mr. Alderman Wire.

It will be seen that this List contains the names of some of the exrliest and most distinguished Members of the Society. The Earl of ABerDEen, who was President of the Society of Antiquaries when the Camden Society was established, gave it the advantage of his public support at a very early period; and the names of the Rev. BuLKELEY B. BANDiNEL, Bodley's Librarian at Oxford; Sir Henry Bunbury; G. G. Cunningham,Esq.; Miss Richardson Currer; Charles William Halletp, Esq.; Thomas Mason, Esq.; and Sir John Edward Swinburne, will all be found in the First Annual List of the Members of the Camden Society.

Although the number of Members whose loss the Society has thus to regret is not much above the usual average; yet the List has been so greatly reduced of late years that the proportion is a large one, and the Council would urge upon the Members to lose no opportunity of bringing the Society under the notice of such of their friends as are interested in the study of any of the branches of our Civil, Ecclesiastical, or Social History.

The Council having understood that Gentlemen desirous of joining the Camden Society have been deterred from giving in their names by the expense of procuring the publications of past years, have recently 
directed that New Members should be allowed to purchase the publications of past years, so far as they can be supplied, at the rate of ten shillings for each year's books, with the exception of those of the last two years preceding their admission, the price of which has been fixed at thirty shillings. The impression of each work now published by the Society is strictly limited to six hundred.

The following Articles have been added to the List of Suggested Publications during the past year.

I. A Series of Descriptions of Pope Alexander VII. and his Cardinals, from the MS. Notes of Dr. John Bargrave. To be edited by the Rev, Canon RoBertson.

II. A Series of News Letters, written by John Chamberlain, Esq. to Sir Dudley Carleton during the reign of Elizabeth, from the Originals in the State Paper Office. To be edited by Miss Williams.

III. Notes of Speeches in the Parliament of 1610, from MSS. in the British Museum. To be edited by S. R. Gardiner, Esq.

IV. Cromwell and Barrington Correspondence, from the Originals in the possession of Allan Lowndes, Esq. of Barrington Hall, Essex. To be edited by Jantes Crosbr, Esq. F.S.A.

V. An account of Sir John Mason, in the time of Elizabeth; and a Discharge of Dethick, Garter, for Expenses of the Funeral of Mary Queen of Scots.

VI. List of the Walloons resident in England in the time of James the First, with other Documents of a similar character. To be edited by W. Durrast Cooper, Esq. F.S.A.

VIII. Early English Poems, from a MS. in the possession of the Dean and Chapter of Windsor. To be edited by B. B. Woodward, Esq. F.S.A., Librarian to Her Majesty.

Several of these are short works, and are intended for publication in the next volume of the Camden Miscellany.

The Books of the present year are two in number :

I. Narratives of the Days of the Reformation, and the contemporary Biographies of Archbishop Cranmer : selected from the Papers of John Foxe the Martyrologist. Edited by John Gough Nichols, Esq. F.S.A.

II. Correspondence of King James VI, of Scotland with Sir Robert Cecil and others during the Reign of Queen Elizabeth. Edited by JoHn Bruce, Esq. V.P.S.A.

The former of these Volumes has met with due commendation from the Reviewers. Edited with the fullness and care which distinguish all $\mathrm{Mr}$. Nichols's works, it cannot fail to take its place among the most reliable authorities for one of the most important periods in our history.

The latter volume will be not less serviceable to the historical inquirer. Derived from the collections of the Marquess of Salisbury at Hatfield, it lays open for the first time the real Secret Correspondence between King James and Sir Robert Cecil, and will be found to be full of valuable information with reference to transactions at the close of the reign of Queen Elizabeth. 
Both works will do credit to the Society, and are manifest evidences of its continued importance and usefulness.

Mr. Collier, who has served the Society as Treasurer for sixteen years, has been desirous for some time past to relinquish the duties of that office, on the ground of increasing years. Mr. Collier having again pressed his retirement upon the Council, Mr. Blaauw has kindly consented to assume the post, and will be proposed for election at the first meeting of the New Council. The Council need scarcely recommend to the Society the propriety of passing a vote of grateful recognition of Mr. Collier's long and valuable services, which will still however be continued to the Society as one of the Council.

Another change is also about to take place in the conduct of the affairs of the Society, in the retirement of $\mathrm{Mr}$. Thoms from the management of the accounts, an alteration rendered necessary by the pressure of other official engagements. The Society will, however, retain his valuable services as Honorary Secretary. Any inconvenience which might have resulted from this change has been obviated by the kindness of Mr. John Gough Nichols, who has offered to take upon himself the whole responsibility of the correspondence in connection with the Subscriptions. The Council have gladly availed themselves of this offer, and have to intimate that all payments of subscriptions and correspondence respecting the accounts should in future be addressed to Mr. John Gough Nichols, and that post-office orders should be made payable at the office in Parliament Street.

The Council would not endeavour to conceal from the Society that its position, although perfectly secure, being without debt, and having an investment of $£ 1,0163 s$. $1 d$., is not so satisfactory as it bas been. New Members do not join the Society so rapidly as the old ones fall off, and the income and consequent means of usefulness have decreased. The sphere open to the Society seems clear, and the publication of such books as those already mentioned, and Chamberlain's Letters during the reign of Elizabeth, which will be the first volume of the next year, supply ample proof that the disappearance of the Camden Society would be a great loss to historical literature.

It is to be hoped that such publications will tend to recruit the number of Members, and restore the income of the Society to its old amount.

\section{By order of the Council,}

\section{John Bruce, Director.}

William J. Thoms, Secretary.

17 April, 1861. 


\section{REPORT OF THE AUDITORS.}

$W_{E}$, the Auditors appointed to audit the Accounts of the Camden Society, repor to the Society, that the Treasurer has exhibited to us an account of the Receipts an Expenditure from the 1st of April, 1860, to the 31st of March, 1861, and that w have examined the said accounts, with the vouchers relating thereto, and find the sam to be correct and satisfactory.

And we further report that the following is an Abstract of the Receipts an Expenditure during the period we have mentioned.

Receipts.

By Balance of last year's account. . Received on account of Members whose Subscriptions were in arrear at the last Audit. . ........ The like on account of Subscriptions due lst May last (1860) .. due lst May next.............. One year's dividend on $£ 10163$ s. 1 d. 3 per Cent. Consols, standing in the names of the Trustees of the Society, deducting Income Tax. .
E. s. $d$.

$\begin{array}{lll}96 & 3 & 7\end{array}$

$\begin{array}{lll}73 & 0 & 0\end{array}$

\begin{tabular}{ccc}
73 & 0 & 0 \\
\hline & 0 & 0
\end{tabular}

1500

$29 \quad 4 \quad 4$
Expenditure.

Paid for printing 600 copies of " Carew Letters" ..... Paid for printing and paper of 750 copies of "Narratives of Reformation ".................. 18617

Paid for binding 500 copies of "Milton Papers" .... 170

The like of "Carew Letters" and "Narratives of Reformation"...................... 3917

Paid for Paper ......................... 4118

Paid for Transcripts........................ 124

Paid for Miscellaneous Printing................ 518

Paid for delivery and transmission of 500 copies of "Carew Letters" and of "Narratives of Reformation," with paper for wrappers, warehousing expenses, \&c. ........................... 19 y

Paid for Advertisements. .................... 412

One year's payment for keeping Accounts and General Correspondence of the Society .............. 5210

Paid for postage, carriage of parcels; and other petty cash expenses......................... 37

And we, the Auditors, further state, that the Treasurer has reported to us, tha over and above the present balance of $\$ 799 s .1 d$. there are outstanding various sub scriptions of Foreign Members, and of Members resident at a distance from Londor which the Treasurer sees no reason to doubt will shortly be received.

Henry Stone Smith. William Salt.

17th April, 1861. 